\title{
The Influence of Mathematical Thinking Skill Toward the Knowledge of Accounting
}

\author{
Sakti Alamsyah \\ \{saktialamsyah1958@gmail.com\} \\ Universitas Muhammadiyah Sukabumi, Indonesia
}

\begin{abstract}
The problem identified in the research was the lack of accounting knowledge, primarily that of the aspect of skill on vocational high school students. The research was aimed at determining the amount of influence of mathematical thinking skill toward the knowledge of accounting. The above result was studied by a theory applied in the research; the three components of learning-teaching process theory from Loree [1]. The research method applied was Explanatory Survey Method, by means of testing instrument and 215 samples consisting of vocational high school students throughout Area II of Bogor. The technique of analyzing data applied was regression. The result of the research shows that mathematical thinking skill is influential toward the knowledge of accounting. The result, thus, shows that mathematical thinking skill takes positive effect on the knowledge of accounting. It is concluded from the research that the knowledge of accounting is influenced by mathematical thinking skill. Therefore, it is suggested that the enrollment of the accounting vocational school students utilize the testing instrument of mathematical thinking skill of mathematics.
\end{abstract}

Keywords: Accounting Knowledge, Critical Thinking Skill.

\section{Introduction}

The mathematical thinking skill is an empowerment of thinking potentials that include the skills of understanding, analyzing, hypothesizing, internalizing, applying and calculating, all in all are the input for the existence in understanding accounting knowledge.

In achieving the qualified study result, one of numerous methods is by implementing revitalization for teacher resources. However, in accepting the students, it has to notice the readiness and learning experience of the students, particularly in financial fields of science. As in vocational high school, the mathematical thinking skill becomes important.

A study conducted by Warsono [2] shows that the mathematics which has long been applied in accounting has not received proper attention in the development of modern accounting so far. Subsequently, Warsono suggests that the application of mathematics in accounting need to get early handle so that the calculation will give significant contribution toward academic world. Accounting deals with numbers. The students must be able to understand such numbers in order that they are competent in working on several basic calculations in terms of addition, diminution, division, multiplication, fraction and percentage. Therefore, it is compulsory for the students to have the skills of understanding, analyzing, hypothesizing, internalizing, implementing, and calculating in order to solving various problems related to number on paper; it is what is called as mathematical thinking skill. 
Another study, conducted by Mahrousa [3], brings about similar result that there is significant influence between verbal skill, mathematical skill and learning motivation toward achievement in studying accounting.

\section{Developing the Hypothesis}

Basically, mathematical thinking skill is an essential skill that is necessary to be possessed and developed by students in studying mathematics. A ratio which supports such statement is that such skill is in line with the vision of mathematics, the aim of national education, and the aim of mathematics study needed to deal with this very competitive atmosphere.

Mathematics is a knowledge required by mankind to fulfill their life needs, as well as to learn other knowledge and sciences. [4]. Mathematics can also be termed as a structure of relationships that relate symbols. This view is based on the thoughts of how mathematics is formed. Therefore, Ruseffendi states that mathematics is formed as a result of thinking of human related to idea, process and intellectual [5].

In the correlation with the potentials owned by human, the mathematical skill is an intelligent study. Binet and Simon defines intelligence as a skill consisting of three components; a) a skill to direct mind and action, b) a skill to change the direction of an action after it has been acted, c) a skill for self-criticizing [6]. In line with that statement, David Wechsler defines intelligence as a totality of someone's ability to strive an action with certain purpose, to think logically, and to face the environment effectively [6]. Both, Binet and Theodore, as well Wechsler's statements imply that mathematics has a power for internalizing human's action in science. Meanwhile, Gardener [7] states that logical-mathematical intelligence is a capability for calculating, quantifying, formulating proportion and hypothesis, and solving complex calculations. For instance, mathematician, accountant, engineering, and so on.

The logical-mathematical intelligence variable $(\mathrm{X})$ refers to an Image. This variable is basically obtained from the students' mathematical thinking skill scores. As the students' score gets higher, so the perception toward their mathematical thinking skill will elevate as well. Referring to Allendoerfer [8], Ismail et al [5] and Hudoyo [9], the mathematical thinking skill is measured by the dimension of understanding skill, of which the indicators are to identify and understand the problem; the dimension of analyzing skill, of which the indicators are able to distinguish any similar cases and to provide the problem solving alternative; the dimension of hypothesizing skill, of which the indicators are able to give temporary answers properly and to predict; the dimension of internalizing skill, of which the indicators are able to memorize the materials within his/her own memory and to reutter that materials. The dimension of implementing skill, of which the indicators are able to apply mathematical thinking in daily life and to apply formulas and/or theories in daily life as well; the dimension of calculating skill, of which the indicators are to study mathematics joyfully and able to work on mathematics operation quickly.

The description of this variable is basically obtained from the questionnaires of students' perception toward mathematical thinking skill. The higher someone's score is, the higher his/her mathematical thinking skill is.

Accounting is defined as a discipline of science and/or activity that provides information needed to run an event efficiently and to evaluate an event of an entity or financial transaction. 
If accounting is seen from the process of its activity, it can be terminologically defined as a process of recording, classifying, summarizing, reporting, and analyzing financial data of an entity [10].

The knowledge of accounting variable (Y) refers to Hasan [11] which consists of accounting working field dimension, financial accounting cycle, and data obtained from test. The data are measured by test. The description of this variable is basically obtained from students' perception questionnaires scores toward accounting knowledge. The higher someone's score is, the higher his/her skill of accounting knowledge is.

According to the above thinking, therefore, students that study accounting has to possess mathematical thinking skill. For this reason, the hypothesis of this research is that mathematical thinking skill positively influences the knowledge of accounting.

\section{Research Methods}

The method applied in this research was verificatively descriptive. The population of this research were all students of vocational high school majoring Business and Management with accounting expertise grade XIII in Area II of Bogor that have A accreditation, and precisely amounted to 980 students in ten vocational high schools. The sample size was selected to 215 students of vocational high school in Bogor, Sukabumi and Cianjur. The instruments of collecting data were:

1. Questionnaire. This questionnaire is constructed and tested by the researcher, as well as being put upon validity and reliability test.

2. Test. The test is used to measure the knowledge of accounting, beside validity and reliability test, it is also conducted the discrimination and difficulty tests.

The data analysis in this research applied singular regression, for it is used to predict the amount of the influence of mathematical thinking skill variable toward accounting knowledge.

\section{Results and Discussion}

Empirically, the hypothesis test shows that mathematical thinking skill gives positive and significant influence toward the knowledge of accounting. The acceptance of this hypothesis supports the study achievement theory which states that teaching-learning process is influenced by raw input (potentials owned by students) which is a stimulus, in which mathematical thinking skill supports students' skill in the achievement of studying accounting. The influence of mathematical thinking skill toward the knowledge of accounting is amounted to $4,50 \%$. The high level of mathematical thinking skill is reflected by the high dimension and indicator of mathematical thinking skill variable. The highest dimension is the skill of understanding, which is amounted to $3,39 \%$, while the lowest is the skill of calculating, which is amounted to $3,02 \%$.

The low mathematical thinking skill shows that studying accounting prioritizes a change toward a more directed accounting skill supported by mathematical thinking skill and wellplanned by the school that run a selection for mathematical thinking. It means that accounting students of vocational high school are required to follow the selection test of mathematical thinking skill. For this reason, the supports given by school institution is not only to accept accounting students of vocational high school, but to consider their quality as well. 
The acceptance of this hypothesis test is reflected from the high dimension and indicator from the mathematical thinking skill variable. This variable, in average condition, brings about the dimension of understanding skill as the highest dimension, while the lowest is the calculating skill.

The data process shows that the skill of understanding is measured by five items showing higer condition than other dimensions, which is amounted to $67,83 \%$. This result can be seen from the indicator of "able to distinguish", which is amounted to $68,84 \%$, while the skill to understand problem is amounted to $66,56 \%$. The indicator "able to distinguish" is the highest among all, this is due to the skill of distinguishing becomes the main factor in analyzing transaction. The skill of understanding which is the highest in this research is in line with the statement of Munandar [12] that especially the learning process in accounting vocational high school, the skill of understanding becomes the core skill in mathematical thinking skill.

The dimension of analyzing skill is amounted to $65,10 \%$ in average condition. The highest indicator is the skill of distinguishing cases, which is amounted to $66,17 \%$, while the skill of giving alternative is amounted to $63,49 \%$, which becomes the lowest. This result shows that accounting vocational high school students have possessed skill in financial transaction cases.

The dimension of hypothesizing skill is amounted to $63,10 \%$ in average condition. This amount shows that the student's skill in thinking mathematically is adequate. It means that students have well mathematical thinking skill. The highest indicator is able to give temporary answers, which is amounted to $63,26 \%$, while the lowest indicator is the skill of predicting, which is amounted to $62,80 \%$. This result shows that vocational high school students in Area II of Bogor that majors accounting have well mathematical thinking skill.

The dimension of internalizing is amounted to $61,24 \%$ in average condition. This amount shows that the students' skill in saving mathematics materials is adequate. It means that students have been able to memorize and reutter mathematics materials following to learning process. The highest indicator is memorizing material, which is amounted to $61,12 \%$, while the lowest indicator is the reutter skill, which is amounted to $59,81 \%$. This condition shows that students are somewhat hardened in reuttering the mathematics materials they have saved before.

The dimension of implementing skill is amounted to $61,24 \%$ in average condition. This amount shows that the students' skill in realizing mathematics materials is adequate. It means that students have been able to apply mathematics learning result in accounting. The highest indicator is the skill of applying mathematics formula, which is amounted to $61,58 \%$, while the lowest indicator is the skill of being able to apply the materials in daily life, which is amounted to $60,56 \%$. This result shows that accounting vocational high school students in Bogor have been able to implement mathematics materials in the real economics transaction.

The dimension of calculating skill is amounted to $60,30 \%$ in average condition. This amount shows that the skill needed in sustaining the learning process achievement is good enough. It means that students have possessed calculating skill to be applied in accounting. The highest indicator is to learn joyfully calculating, which is amounted to $63,16 \%$, while the lowest indicator is the skill of calculating operation quickly, which is amounted to $57,44 \%$. This condition shows that accounting vocational high school students have much skill in indulging calculating than operating calculation quickly.

The knowledge of accounting variable can be described for its influence by the mathematical thinking skill, which is amounted to 0,169 or $16,9 \%$, and classified in average condition. Therefore, it can be concluded that the knowledge of accounting is influenced positively and significantly by mathematical thinking process. The higher the mathematical 
thinking skill is, the more positive the knowledge of accounting is. For this reason, mathematical thinking skill is a significant variable to receive more attention in explaining the knowledge of accounting variable, as well as to receive attention from formal education implementation, particularly in vocational high school with accounting expertise, mainly in transforming the knowledge of accounting and accounting values toward vocational high school students.

Therefore, mathematical thinking skill is the strongest porter of stimulus in improving the knowledge of accounting that can be firstly implemented through the entrance test of accounting vocational high school. By using the intelligence, it is proven that mathematical thinking skill plays a high role in improving the knowledge of accounting.

\section{Conclusion}

Mathematical thinking skill positively influences the knowledge of accounting. It means that the higher mathematical thinking skill is, the higher the knowledge of accounting is. Based on the result of the research, it is suggested to improve the indicators of mathematical thinking skill, mainly the lowest indicators, so that the mathematical thinking skill is able to play a role in elevating the innovative learning process. From the dimension of understanding skill, one indicator that should get improvement is the skill of understanding problem. From the dimension of analyzing skill, it is the skill of providing alternative that should be improved. From the dimension of hypothesizing skill is the skill of predicting, while from the dimension of internalizing skill is to be able to reuttering. From the indicator of implementing skill is to implement the materials in daily life, while from the dimension of calculating skill is the ability to operate quick calculation.

\section{References}

[1] M. R. Loree, Psychology of Education. New York: The Ronald Press, 1970.

[2] S. Warsono, “Akuntansi ternyata Logis dan Mudah," Yogyakarta: Asgard Chapter, 2009.

[3] A. N. S. Mahrousa, "Pengaruh Kemampuan Verbal, Kemampuan Matematika, dan Motivasi Belajar Terhadap Prestasi Belajar Mata Pelajaran Akuntansi Siswa Kelas 2 SMA Negeri 2 Demak." Universitas Negeri Semarang, 2009.

[4] H. Retnawati, "Pengaruh kemampuan awal dan kemampuan berfikir logis/penalaran terhadap kemampuan matematika," in Makalah disajikan pada Seminar Nasional Pendidikan Matematika, Universitas Negeri Yogyakarta, Yogyakarta, 2009.

[5] et al. Ismail, Kapita Selekta Pembelajaran Matematika. Jakarta: Universitas Terbuka, 1998.

[6] S. Azwar, Pengantar Psikologi Inteligensi. Yogyakarta: Pustaka Pelajar, 2004.

[7] N. Syaodih Sukmadinata, "Metode Penelitian Pendidikan," Bandung: Rosda, 2007.

[8] C. B. Allendoerfer, "The dilemma in geometry," Math. Teach., vol. 62, no. 3, pp. 165-169, 1969.

[9] H. Hudojo, "Mengajar belajar matematika," Jakarta: Depdikbud, 1988.

[10] U. Muawanah and F. Poernawati, "Konsep Dasar Akuntansi dan Pelaporan Keuangan, jilid 2 untuk SMK," Jakarta Direktorat Pembin. Sekol. menengah Kejuruan, Direktorat Jenderal Manaj. Pendidik. Dasar dan Menengah, Dep. Pendidik. Nas., 2008.

[11] S. H. Hasan, "Inovasi Untuk Meningkatkan Kualitas Pendidikan IPS," in Makalah Seminar Pendidikan IPS, Program Studi Pendidikan IPS Sekolah Pascasarjana, UPI, 2012, vol. 12.

[12] S. C. Utami Munandar, "Perkembangan Kreativitas Anak, Festival Tari Anak-anak 1998," Denpasar, Bali, 1998. 